Article

\title{
Journalism Expands in Spite of the Crisis: Digital-Native News Media in Spain
}

\author{
Samuel Negredo ${ }^{1, *}$, María-Pilar Martínez-Costa ${ }^{1}$, James Breiner ${ }^{2}$ and Ramón Salaverría ${ }^{1}$ \\ ${ }^{1}$ Department of Journalism Projects, University of Navarra, 31009 Pamplona, Spain; E-Mails: negredo@unav.es (S.N.), \\ marcosta@unav.es (M.-P.M.-C.), rsalaver@unav.es (R.S.) \\ 2 Department of Marketing and Media Management, University of Navarra, 31009 Pamplona, Spain; \\ E-Mail: jbreiner@unav.es \\ * Corresponding author
}

Submitted: 19 December 2019 | Accepted: 2 March 2020 | Published: 16 April 2020

\begin{abstract}
Digital-native news organizations have grown steadily in Spain since the mid-1990s and they have become established as a major force in the media market. Paradoxically, their biggest expansion coincided with the Great Recession (2008-2014). In fact, their numbers increased most during 2012-2013, when traditional media were cutting staff in response to the economic crisis, and unemployment rates in the media sector as a whole hit their peak. However, these digital-native news startups have yet to prove their sustainability and stability. This study uses our own database of 3,862 native and nonnative digital news outlets in Spain and the Reuters Institute Digital News Report to analyze a number of characteristics of these media, such as the percentage that have gone inactive, the relative popularity of legacy brands vs. digital natives, multi-platform synergies, content subject matter, geographical location, ownership, and funding sources. Based on these quantitative parameters, this study reviews the structural strengths and weaknesses of digital-native media in the Spanish news market. Taking into account these findings, we conclude that the surge in digital-native news media observed in Spain during the Great Recession followed the pattern of creative destruction described by several economists.
\end{abstract}

\section{Keywords}

digital journalism; digital-native media; media economics; online news; Spain

Issue

This article is part of the issue "Digital Native News Media: Trends and Challenges" edited by Ramón Salaverría (University of Navarra, Spain).

(C) 2020 by the authors; licensee Cogitatio (Lisbon, Portugal). This article is licensed under a Creative Commons Attribution 4.0 International License (CC BY).

\section{Introduction}

Digital journalism is entering its third decade in Spain, and the industry and the way people consume news is changing faster than ever. Since their inception in the middle of the $1990 \mathrm{~s}$, online properties rooted in traditional or legacy media dominated the digital market; nevertheless, digital-native media have advanced to a key position in the reconfiguring of the media ecosystem (Salaverría, 2019). The purpose of this study is to review the structural strengths and weaknesses of digitalnative media in the Spanish news market by looking at the number and the types of sites emerging from the Great Recession.

In 2019, digital-born media made up $46.4 \%$ of all active digital publications in this country, according to our research, and they represented an expanding, diversified, and developed sector, building on the trend signaled in previous studies (Salaverría, Martínez-Costa, \& Breiner, 2018). Besides increasing and broadening the supply of content, digital-native media have gained more followers every year: When asked about the kinds of media they used weekly for news, $21 \%$ of adult online news users in Spain said they used digital-native sites and apps. 
When asked about news brands of all kinds, $57 \%$ of users remembered having used a digital-native news brand in the last week and such use was highest among young people (see Table 1).

This growth in the demand and supply of digitalnative media in Spain is occurring in a financial and political environment that makes it hard for digital media to survive. The first decade of the millennium was "one of creative destruction in the news industry across Western Europe" (Bruno \& Nielsen, 2012, p. 3), that was "dismantling the traditional financial media configurations" (Picard, 2014, p. 273). Spain was no exception and the economic crisis accentuated the erosion of the media model with years of decline in sales and advertising (Salaverría \& Gómez-Baceiredo, 2017).

The economic revitalization that followed those years of crisis in Spain generated an improvement in the general media situation with new investments (de Toro et al., 2017, pp. 21-25). Nevertheless, political action at a national level ground to a halt, with no stable majorities in Parliament, four general elections in four years, and in 2019 the economy slowed down.

Paradoxically, despite this uncertain context, the number of digital-native media has increased, driven by technology and audience demand. These emerging media in many cases have become leading innovators in production and narrative forms, thus improving the quality of content (García-Avilés \& González-Esteban, 2012).

The business of media is changing, too, but not at the pace that some expected. For the moment, neither legacy media nor digital-native media can do without advertising or choose to close off their online editions with paywalls entirely. In 2018, the Spanish press generated 486,9 million euros in traditional advertising, a decline of $6.8 \%$ year-on-year. But that reduced total is still more than their combined digital ad revenue of 319,9 million euros, which grew by $15.8 \%$ over the previous year. Nor can digital-native media manage without advertising: In 2018, they received 205 million euros from that source, up $9.5 \%$ from the previous year (Asociación de Medios de la Información de España, 2019).

At the same time, some digital-native operations are complementing advertising with user revenue. They focus on building the size and loyalty of their audience with unique content that people will be willing to pay for. In some cases, a media organization with free content asks users to make a voluntary payment-a one-off donation or a membership with recurring fee-to support qual- ity, independent journalism (González-Esteban, 2014). In other cases, they establish a metered paywall that grants users access to a limited number of articles before requiring them to pay, or they restrict access to more distinctive or exclusive content. In all cases, the user's willingness to pay is based on the media organization's developing a relationship of trust and service with the audience.

\section{Theoretical Framework}

\subsection{Digital-Native News Media and Creative Destruction}

Since Schumpeter (1942) popularized it, the concept of creative destruction has been one of the most used since the mid-twentieth century to describe the processes of change in any industry of the market economy. This concept describes the innovation process under which new products that are launched to the market tend to destroy established companies and their business models. The theory of creative destruction proposed by the Austrian economist has gained special prominence in the last quarter of the century with the digital economy, where new actors have destabilized not only some companies-there are well known cases such as Kodak and Blockbuster (Foster \& Kaplan, 2011; Gershon, 2013) - but even complete industries, such as music (Ku, 2002). The news media industry has been another clear example of this process (Schlesinger \& Doyle, 2015).

Since the 1990s, new actors have burst into the legacy media industry whose competition, at first, was undervalued by many media managers. For example, the renowned media analyst Howard Kurtz (2002) in The Washington Post used these deprecatory words to describe the search engine that was to become the main competitor of the media in the following decade: "Google is a mere conveyor belt that delivers all kinds of infomatter without the slightest judgment." In effect, the new actors-technology providers, search engines, online stores, social networks-were frequently considered as mere outsiders of the journalistic business, not direct competitors of traditional media. However, in the emerging attention economy, the downturn of the legacy media caused by these successful internet start-upsApple, Google, Amazon, Facebook-soon revealed their profound and long-lasting disruptive effect. Confirming Schumpeter's theory, the creativity and innovation of the new competitors triggered a process of rapid destruction of legacy media companies (Pérez-Latre, 2014).

Table 1. Kinds of brands used for checking the news online in the last week ( $N=2005$, January 17-February 21, 2019).

\begin{tabular}{lccccccccc}
\hline Kinds of online media brands & Total & Men & Women & $18-24$ & $25-34$ & $35-44$ & $45-54$ & $55-64$ & $65+$ \\
\hline Print-native & $69 \%$ & $73 \%$ & $65 \%$ & $75 \%$ & $73 \%$ & $74 \%$ & $66 \%$ & $65 \%$ & $66 \%$ \\
Broadcast-native & $60 \%$ & $62 \%$ & $58 \%$ & $61 \%$ & $64 \%$ & $61 \%$ & $59 \%$ & $59 \%$ & $56 \%$ \\
Digital-native & $57 \%$ & $58 \%$ & $55 \%$ & $67 \%$ & $66 \%$ & $61 \%$ & $53 \%$ & $51 \%$ & $48 \%$ \\
\hline
\end{tabular}

Note: Question: "Which of the following brands have you used to access news online in the last week (via websites, apps, social media, and other forms of Internet access)? Please select all that apply." Source: Reuters Institute Digital News Report survey 2019, conducted by YouGov (Vara-Miguel, Negredo, Amoedo, \& Moreno, 2019). 
To stand up to the new competitors, news media companies have developed different innovation strategies, with different outcomes. The most widespread and common strategy has been multi-platform diversification (Doyle, 2013), frequently guided by consulting companies that oriented media companies in their strategic decision-making. In other cases, news media companies have tested internal innovation strategies, such as creating laboratories for technological development, developing new storytelling formats, and exploring new business models (Salaverría, 2015). Some newspaper companies have also experimented with intrapreneurship, by sponsoring start-ups, thus emulating their powerful digital competitors (Boyles, 2016; Hass, 2011). The truth, however, is that these measures have barely managed to lessen the devastating impact of large digital companies on the legacy media business.

In recent years, a second wave of creative destruction can be noticed in the media industry. If in the first wave the impact was made by companies coming from outside the news media industry, in this second wave the competitors emerged from journalism itself: digitalnative media. Their degree of disruption in the journalism industry seems to be smaller than that of the great internet companies. However, the disruption by digitalnative news media is still noticeable (Salles, 2019), even if they play with similar rules and suffer similar problems to those of the legacy media. Like traditional media, digital-native media seek to gain the public's attention and confidence through a quality news service. Once the public's trust is obtained, they aspire to build a sustainable business model, either through advertising, subscriptions, or through other formulas. This is a growing competition, in which traditional media have the advantage of their brand recognition, but where digital-native competitors also have their assets: usually their greater ease of adaptation to the dynamics of the Internet, a closer relationship with the public, and less burdensome production structures (Nee, 2013).

\subsection{Great Recession and Digital-Native News Media}

Our objective was to explore a somewhat counterintuitive phenomenon: the fact that there was a massive launching of digital-native publications during the Great Recession (Grusky, Western, \& Wimer, 2011), which in the case of EU countries occurred during the late 2000s and early 2010s. While in those years almost all European legacy media companies were seriously hurt by the most severe economic crisis in decades, quite surprisingly digital-native news media began to thrive, at least in quantitative terms. This phenomenon was particularly noticeable in the countries most seriously battered by the crisis, like Spain. Why?

Scholars have studied extensively how the news media covered the economic crises (e.g., Arrese \& VaraMiguel, 2016; Boomgaarden, van Spanje, Vliegenthart, \& de Vreese, 2011; Vliegenthart \& Mena Montes, 2014), but not so much how the crises, more specifically the Great Recession, affected the media (e.g., Almiron \& Segovia, 2012). This impact was very noticeable, though.

According to the figures compiled by the Asociación de la Prensa de Madrid (APM, 2015), Spanish media laid off almost 12,000 journalists between 2008 and 2015. Those same years of the crisis saw the closing of 214 magazines, 38 daily newspapers, 12 free newspapers, and three news agencies. This is just a cautious estimation of the devastating effects of the crisis in Spanish media industry, according to the report (APM, 2015, p. 92).

While those legacy media were closing, a countertrend was under way. The APM found that journalists launched 579 news startups in Spain, mostly digital, during that eight-year period. Startups in any industry have a high failure rate, and these were no different. By the end of 2015, a fifth of them had closed, which suggests that many of them had weak fundamentals and were poorly planned (APM, 2015, p. 82).

In line with the theoretical framework and industry context outlined above, we pose the following research questions:

RQ1: How did the number of digital-native news sites in Spain develop during the Great Recession?

RQ2: What types of digital-native news media emerged from the Great Recession?

\section{Methodology}

This study aims to specify the features of the digital news market in Spain; in particular, the contents, mono- or multi-platform nature, geographical location, ownership, and funding sources of digital-native news media, as well as the popularity of the main brands of this kind among online news users, compared with the online reach of legacy media.

Digital-native news media in Spain are described based on our own comprehensive database, which takes the form of a collaborative spreadsheet, with 73 columns for variables, started in 2017, with annual updates. It catalogued 3,862 brands in November 2019. The entries for each digital-native media outlets identified in an earlier study (Salaverría et al., 2018) were updated, in terms of reviewing the status and details of existing cases, and the latest launches were also added and classified.

The searching and coding were performed by a trained team of four senior researchers in the USPRINME (2016-2018) and DIGINATIVEMEDIA (2019-2021) projects, affiliated with this research, with additional support from three students for less than $4 \%$ of the entries. The students' coding was later checked and validated by the senior researchers. This team produced over 280,000 data cells, a selection of which have been used for the present study.

Inter-coder reliability test results are not available because coding decisions were easily observable by looking 
for specific elements designated in the coding procedure for each variable, and they did not require the coder's interpretation. In order to maximize the accuracy and the currentness of the data, in the context of ongoing updates, we developed a codebook that we revised after a pilot study; we conducted peer-to-peer training for each of the coders, and the team maintained fluid communication to solve disputes. At least two different coders reviewed each entry in different moments in time, one of which happened during late 2019.

Sources for the inclusion of media in the database included directories and lists managed by public administrations, industry associations, professional bodies, and others kept by the public, as well as industry news. Whenever an outlet was included, as part of the process of identifying its ownership, other titles from the same publishing house were searched for and added if appropriate. This snowball process was completed with suggested related pages and profiles on social networking sites.

In order to avoid duplication, a search query for the outlet's name and URL was performed before adding any candidate site to the database. Periodical reviews based on alphabetical sorting were conducted, including one right before results were extracted and analyzed. For any duplicates detected, data was consolidated and the redundant instance was deleted before analysis.

The analytical variables relevant for the purpose of this piece of research were: presence or absence of the outlet in web, print, broadcast television, broadcast radio, and mobile application (this gave the sum for multiplatform presence and it was used as the basis for the variable of native or non-native medium); current status (active or inactive, if no content had been published in more than three months or if a previously-registered site ceased to be available); launch date/year and closure date/year (the latter, for inactive media only); generalinterest or specialized content scope (for entries classified as specialized, the main content topic and the secondary content topic, following the categories shown in the results section); location at four levels (Autonomous Community/Spanish region, province, municipality, and postcode); public or private ownership; its journalistic or non-journalistic nature, and the presence or absence of seven kinds of funding sources (advertising, sponsored content, subscription, private sponsorship, public sponsorship, donations, and others, which could be specified by coders).

In addition, our database results were compared with the audience performance of digital-native news brands in the Digital News Report survey 2019, conducted by YouGov on behalf of the Reuters Institute at the University of Oxford and partners such as the University of Navarra for the Spanish market (annual, 2014-2019, $\mathrm{N} \approx 2000$ yearly). The survey is representative of adults who were connected to the internet and who consumed news at least once in the last month. This method tends to favor websites accessed directly by users, which they are more likely to identify and remember, and it has a detrimental effect on the performance of outlets depending more heavily on social and search as traffic sources, for which the brands may go unnoticed by users. Based on these quantitative parameters, we offer below a review of the structural strengths and weaknesses of digitalnative media in the Spanish news market.

\section{Results}

\subsection{The Supply of Digital-Native and Legacy News Media}

The 1,382 active digital-native news websites available in Spain in November 2019 are the basis for our detailed study of the sector in this market; these represented $46.4 \%$ of all active news sites at the time, considering as 'active' those outlets which had updated their contents at least once in the last three months. We therefore excluded from further analysis the 1,577 active sites that belonged to brands which continued to have a traditional print (newspaper or magazine), broadcasting (either radio or television), or news agency outlet as their main or original news operation, which represented $52.9 \%$ of active sites (see Table 2 ).

Digital-native media constitute a well-developed sector in Spain that has undergone exponential growth: The first comprehensive study counted a mere 116 digitalnative news media in 2005 (Salaverría, 2008). If the launch date of the sites is considered, the growth and evolution of digital-native media shows strikingly positive years, against a very bleak economic background, which we will now describe before presenting the data of launches by year.

According to the Economically Active Population Survey from the Spanish Institute for National Statistics (Instituto Nacional de Estadística [INE], 2019a), the quantity of unemployed people in the information and communications sector hit 40,000 at the end of 2008, and rose as high as 55,000 in 2012 and 2013. It has descended gradually since, hovering between 24,900 and 36,300 .

Table 2. Count of active and inactive, digital-native and non-native online media in Spain ( $\mathrm{N}=3,862$, November 2019$)$.

\begin{tabular}{lcccccrr}
\hline Status & Digital-native & \% by kind & Non-native & \% by kind & Not determined & \% by kind & Total \\
\hline Active & 1382 & 79 & 1577 & 79.7 & 20 & 14.9 & 2979 \\
Inactive & 368 & 21 & 401 & 20.3 & 114 & 85.1 & 883 \\
Total & 1750 & 100 & 1978 & 100 & 134 & 100 & 3862 \\
\hline
\end{tabular}

Note: The native or non-native nature of 20 active sites $(0.7 \%)$ could not be determined. Source: Authors' own database. 
Those unemployment figures closely track the country's economy as a whole, as measured by Gross Domestic Product (GDP). In the decade running up to the Great Recession, GDP in Spain grew at annual rates between $2.8 \%$ and $5.2 \%$, and it slowed down to a mere $0.9 \%$ in 2008. The worst years were 2009, 2012, and 2013, which saw negative growth of $-3.7 \%,-3 \%$ and $-1.4 \%$, respectively. Since the recovery in 2014 (1.4\%), Spanish GDP reached 3.8\% in 2015 and it slowed down from 3\% in 2016 to $2.4 \%$ in 2018 (INE, 2019b).

However, while the economy struggled and unemployment peaked, digital-native launches more than doubled in 2012 (143) and 2013 (156) in comparison with five years earlier, 2007 (65) and 2008 (66), respectively (see Figure 1). Many of the professionals made redundant by traditional media companies undertook new digital-only projects as a way to face the crisis. 2018 and 2019 data is provisional due to the ongoing nature of the database, which was last updated in November 2019.

Meanwhile, the growth of internet access in Spain expanded the potential audience for digital news media. The share of households with internet access in Spain soared from 36\% in 2007 to $61 \%$ in 2013, and 83\% in 2018 (Asociación para la Investigación de Medios de Comunicación, 2019, p. 65). This growth arguably favored digital natives more than traditional media, whose core revenues did not come from their digital audience.

The years of the Great Recession were an accelerator for the development of digital-native media in Spain.
Figure 2 shows how the overall number of active digitalnative media evolved over time, only considering outlets for which a launch date could be determined.

\subsection{Audiences for Digital-Native Brands among the Top Legacy Competitors}

Digital-native news organizations have managed to occupy an important share of the digital media map, and some of these operations have also earned the readership of large audiences (see Table 3). According to survey data, legacy brands are still a majority in the rankings of the most popular online news sites in Spain. There are five newspaper websites and two private television websites in the first ten places, but notably there are also three journalist-led, digital-native news sites in these top positions.

In the broader ranking of the top 25 news websites, we found long-running, turn-of-the-century digital-native sites, such as El Confidencial (6th) and Libertad Digital (19th), and most importantly for our research interests, there emerged a handful of operations that were a direct result of the economic and political changes affecting the media industry in Spain in the decade of the 2010s: Eldiario.es (4th), Okdiario (10th) and El Español (25th), all founded by former senior editors of print daily newspapers. They are just three successful cases in a broader trend including sites such as VozPópuli, InfoLibre and El Independiente, to name a few in Madrid. Another re-

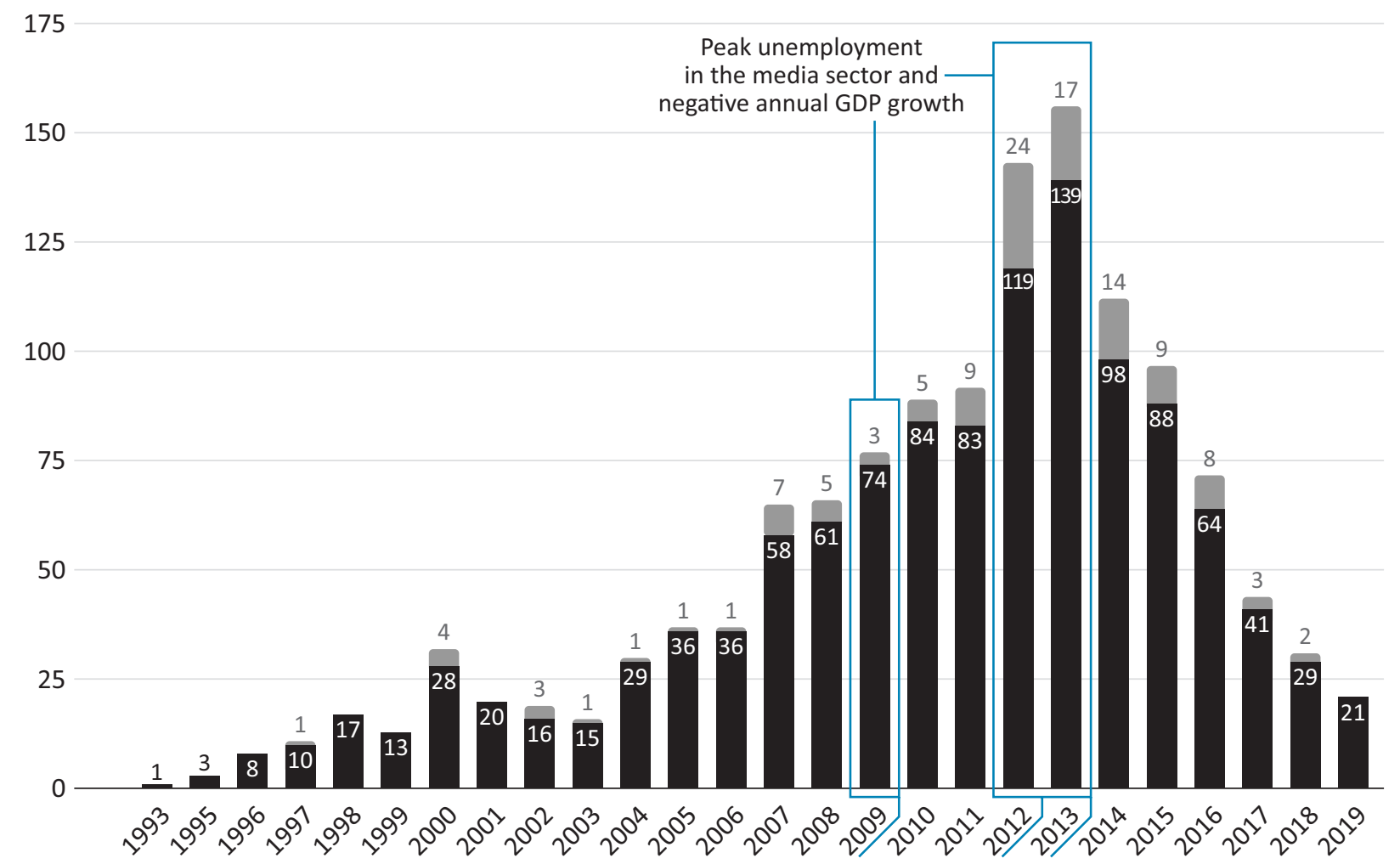

Figure 1. Number of currently active (black) and inactive (gray) digital-native sites in Spain by launch year ( $N=1,750$, November 2019). Note: Year not determined for 164 active and 249 inactive sites. Source: Authors' own database. 
- - Launches by year ..... Closures by year — Active digital-native sites with known launch date (accumulted at the end of each year)

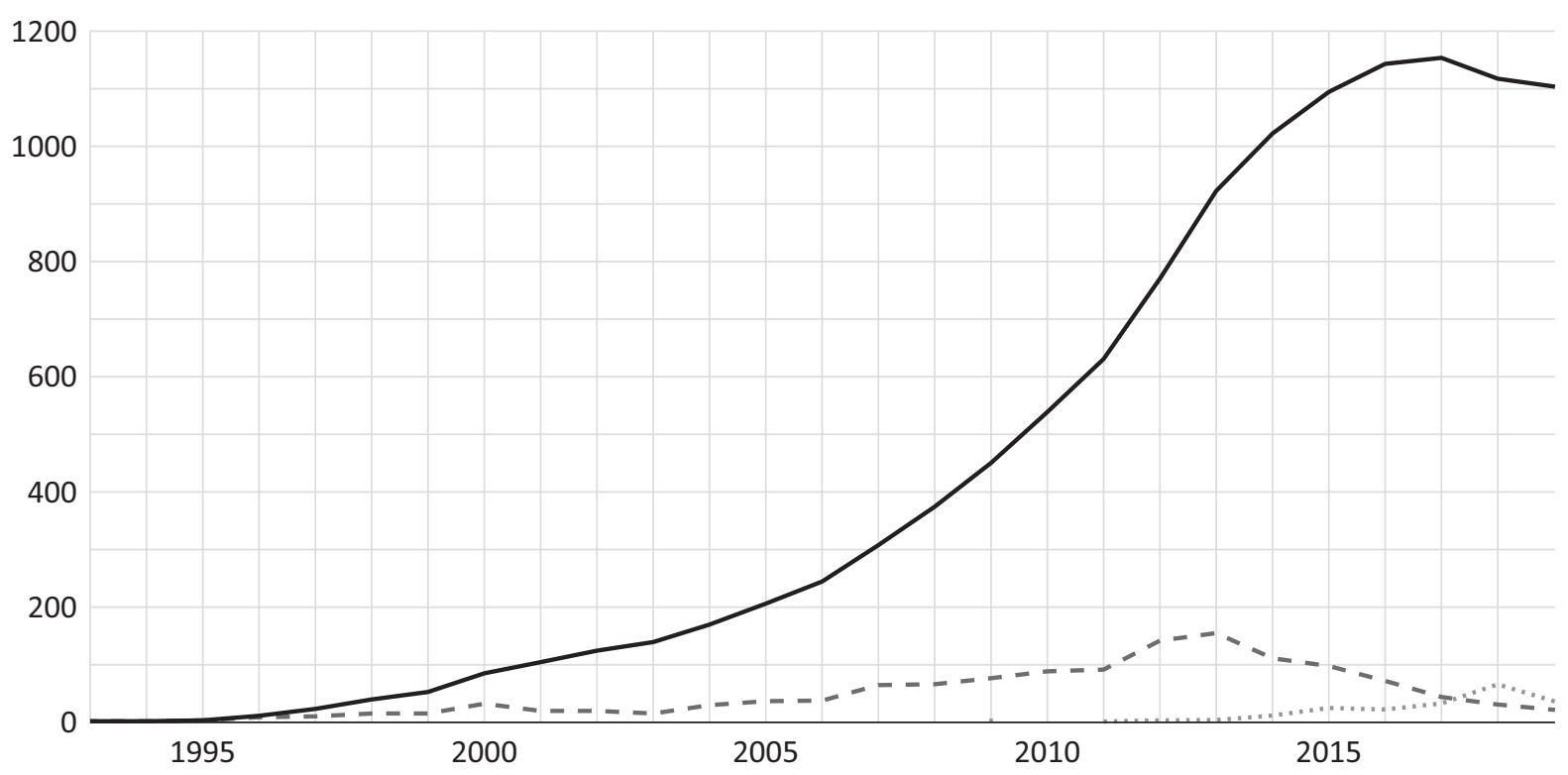

Figure 2. Number of active digital-native sites in Spain with known launch year, by year ( $N=1,750$, November 2019$)$. Notes: Launch year not determined for 164 active and 249 inactive sites. Closure year not determined for 171 inactive sites. Source: Authors' own database.

Table 3. Weekly online reach for news (\%) among adult digital news users in Spain $(\mathrm{N} \approx 2000$, January-February of each year).

\begin{tabular}{|c|c|c|c|c|c|c|c|c|}
\hline Rank & Online brand & Origin & 2019 & 2018 & 2017 & 2016 & 2015 & 2014 \\
\hline 1 & El País & Newspaper & 24 & 27 & 29 & 34 & 23 & 31 \\
\hline 2 & El Mundo & Newspaper & 18 & 22 & 22 & 28 & 18 & 27 \\
\hline 3 & Antena 3 & Television & 18 & 15 & 19 & 23 & 14 & 19 \\
\hline 4 & Eldiario.es & Digital-native & 18 & 18 & 16 & 17 & 8 & 8 \\
\hline 5 & 20 Minutos & Newspaper & 15 & 17 & 17 & 21 & 16 & 18 \\
\hline 6 & El Confidencial & Digital-native & 14 & 19 & 16 & 20 & 10 & 9 \\
\hline 7 & Marca & Newspaper (sports) & 13 & 15 & 16 & 19 & 14 & 22 \\
\hline 8 & La Vanguardia & Newspaper & 13 & 12 & 11 & 11 & 7 & 5 \\
\hline 9 & Telecinco & Television & 13 & 9 & 11 & 13 & 9 & 8 \\
\hline 10 & OKdiario & Digital-native & 12 & 12 & 8 & $\mathrm{~N} / \mathrm{A}$ & $N / A$ & $\mathrm{~N} / \mathrm{A}$ \\
\hline 11 & LaSexta & Television & 12 & 13 & 13 & 16 & 11 & 14 \\
\hline 12 & $A B C$ & Newspaper & 10 & 12 & 11 & 15 & 9 & $\mathrm{~N} / \mathrm{A}$ \\
\hline 13 & El Periódico & Newspaper & 10 & 10 & 11 & 13 & 5 & 9 \\
\hline 14 & RTVE & Television and radio & 10 & 13 & 12 & 16 & 11 & 13 \\
\hline 15 & Yahoo! News & Digital-native (news aggregator) & 10 & 13 & 14 & 17 & 8 & $\mathrm{~N} / \mathrm{A}$ \\
\hline 16 & Público & Newspaper (now digital-only) & 9 & 12 & 12 & 13 & 10 & $\mathrm{~N} / \mathrm{A}$ \\
\hline 17 & MSN News & Digital-native (news aggregator) & 8 & 13 & 10 & 16 & 9 & $\mathrm{~N} / \mathrm{A}$ \\
\hline 18 & La Razón & Newspaper & 8 & 8 & 9 & $\mathrm{~N} / \mathrm{A}$ & N/A & $\mathrm{N} / \mathrm{A}$ \\
\hline 19 & Libertad Digital & Digital-native & 8 & $\mathrm{~N} / \mathrm{A}$ & $\mathrm{N} / \mathrm{A}$ & $\mathrm{N} / \mathrm{A}$ & $N / A$ & $\mathrm{~N} / \mathrm{A}$ \\
\hline 20 & Cuatro & Television & 8 & 7 & 7 & 11 & 6 & 9 \\
\hline 21 & Cadena SER & Radio & 7 & 8 & 8 & 13 & 8 & 10 \\
\hline 22 & El Huffington Post & Digital-native & 7 & 11 & 12 & 14 & 8 & 4 \\
\hline 23 & As & Newspaper (sports) & 7 & 7 & 7 & 8 & 6 & $\mathrm{~N} / \mathrm{A}$ \\
\hline 24 & COPE & Radio & 7 & 7 & 6 & 8 & 4 & 5 \\
\hline 25 & El Español & Digital-native & 6 & 9 & 7 & 7 & N/A & $\mathrm{N} / \mathrm{A}$ \\
\hline
\end{tabular}

Note: Question: "Which of the following brands have you used to access news online in the last week (via websites, apps, social media, and other forms of Internet access)? Please select all that apply." Source: Authors' own based on the Reuters Institute Digital News Report survey, conducted by YouGov (Vara-Miguel et al., 2019). 
markable case is that of Público (16th), the largest brand which, just like other regional and local titles, turned online only as it ceased its daily print operations and it laid off most of its staff. Also among the top sites are the Spanish editions of global news aggregators, namely Yahoo! News (15th) and MSN News (17th), which only offer stories provided by other outlets. Yet one more notable contender is the Spanish edition of HuffPost (22nd), owned and operated by the publishers of El País.

\subsection{Synergies of Digital-Native Media with Traditional Platforms}

Only $15.7 \%$ of active digital-native media had a multiplatform presence that was secondary to the main digital operation-otherwise they would have been coded as non-native-with $13 \%$ of these media being present in two platforms, $2.4 \%$ in three platforms and $0.4 \%$ in four platforms.

Among the 1,382 currently-active sites, 86 (6.2\%) were found to have a mobile application available, either for Android or iOS or for both platforms; 75 (5.4\%) had a print component, such as a free or paid-for magazine or non-daily newspaper that had been launched along with, or later than, the main online operation, either as an offline advertising platform or as an added-value feature for subscribers. On the broadcast side, 50 (3.6\%) had a radio presence, and just as many were present on television; these figures include new, specialized verticals belonging to broadcast media groups, and longrunning independent outlets that had become established as important regional online players and have forayed into broadcasting based on synergies and the decreasing costs of digital production and distribution.

\subsection{General-Interest or Specialized: Topic Scope of Active and Inactive Digital Media}

General-interest contents were present in 806 (58.3\%) of active digital-native media, whereas 576 (41.7\%) focused on specialized topics. The web initially favored targeting niche audiences through specialized content, and then there was an increase in media that chose to supply a menu of general news, with differences in their editorial focus and in how stories were covered and presented in the digital environment (see Table 4).

Active digital-native media covered a wide range of specialized topics. Four in ten of these sites belonged to either of the two leading categories-sports and culture-with more than a hundred brands classified in each of these areas: 116 sites (20.1\% of all active special- ized digital-native outlets) were found to focus on sporting news and results, and 104 covered any or all of the disciplines of culture and the arts (18.8\% of active specialized digital-native sites). Almost one in ten specialized digital-native sites was devoted to leisure and entertainment, with news about showbiz, television, travel, and other pastimes; this category added up to 54 , representing $9.4 \%$ of specialized sites. A very similar proportion was assigned to technical and professional publications (53 and 9.2\%). These were followed by other categories for which there is also an extensive supply of legacy brands. The topic spectrum also reveals that the tastes and preferences of publics change over time and that the media must adapt to the increasingly combined and diversified consumption driven by audiences' habits and choices (see Table 5).

\subsection{Geographical Location in Spain: Metropolitan Madrid and beyond}

The territorial distribution of digital-native news media is not strictly proportional to the population. Most of the digital-native media are concentrated in the most important cities and the regions with higher economic development. There is a metropolitan effect within the country, as the Community of Madrid is home to almost one in three digital-native sites $(383,28.9 \%)$, twice its share of the Spanish population. This is further driven by the fact that the biggest media groups, almost all of them based in the Spanish capital and its surroundings, have a wide portfolio of digital properties.

In most regions, the slight disproportion between the number of digital-native media and the population may result from the limitations of the sources of our censuslike database. Outside Madrid, the larger regions with a high proportion of digital-native media per 100,000 people are sparsely populated areas, such as the Chartered Community of Navarre, with notable capitals and hundreds of small municipalities. On the other hand, regions with higher overall population and population density, such as Catalonia, the Valencian Community, and the Basque Country, show a lower proportion of digital natives. The lowest proportion occurs in Andalusia, ranking third by number of digital-native sites but first by population (see Table 6), which may be linked with lower news readership.

\subsection{Private (and Minimally Public) Ownership}

There were around 1,341 privately owned, digital-native news websites in Spain in business in November 2019;

Table 4. General-interest and specialized digital-native news media ( $N=1,382$, November 2019).

\begin{tabular}{lcccc}
\hline Status & General-interest & \% by status & Specialized & \% by status \\
\hline Active & 806 & 58.3 & 576 & 41.7 \\
Inactive & 201 & 50.1 & 164 & 40.9 \\
\hline
\end{tabular}

Note: Topic scope could not be determined for 36 (8.9\%) of the 401 inactive digital-native sites. Source: Authors' own database. 
Table 5. Main topic focus of active specialized digital-native news media ( $N=576$, November 2019).

\begin{tabular}{lcc}
\hline Topic & Quantity & \% of specialist digital-native sites \\
\hline Sport & 116 & 20.1 \\
Culture (literature, cinema, music, art) & 108 & 18.8 \\
Leisure and entertainment & 54 & 9.4 \\
Technical and professional & 53 & 9.2 \\
Science and technology & 43 & 7.5 \\
Business and finance & 40 & 6.9 \\
Politics & 28 & 4.9 \\
Motor & 23 & 4 \\
Fashion and trends & 21 & 3.7 \\
Health & 17 & 3 \\
Food & 13 & 2.3 \\
Environment & 12 & 2.1 \\
Home and family & 12 & 2.1 \\
Other & 10 & 1.7 \\
Bullfighting & 9 & 1.6 \\
Religion and spirituality & 8 & 1.4 \\
Sexuality & 4 & 0.7 \\
Education & 4 & 0.7 \\
Humor & 1 & 0.2 \\
\hline
\end{tabular}

Source: Authors' own database.

Table 6. Geographical location of active digital-native media ( $N=1,382$, November 2019).

\begin{tabular}{|c|c|c|c|c|c|}
\hline $\begin{array}{l}\text { Autonomous Community } \\
\text { (Spanish region) }\end{array}$ & $\begin{array}{c}\text { Active } \\
\text { digital-native } \\
\text { media }\end{array}$ & $\begin{array}{c}\% \text { of active } \\
\text { digital-native } \\
\text { media }\end{array}$ & $\begin{array}{c}\% \text { of } \\
\text { Spanish } \\
\text { population }\end{array}$ & $\begin{array}{l}\text { Difference in } \% \text { points } \\
\text { between } \% \text { of active } \\
\text { digital-native media } \\
\text { and } \% \text { of population }\end{array}$ & $\begin{array}{l}\text { Digital-native } \\
\text { media } \\
\text { per } 100,000 \\
\text { people }\end{array}$ \\
\hline Community of Madrid & 383 & 28.9 & 14.1 & 14.8 & 5.8 \\
\hline Catalonia & 199 & 15 & 16.3 & -1.3 & 2.6 \\
\hline Andalusia & 130 & 9.8 & 18 & -8.2 & 1.6 \\
\hline Valencian Community & 106 & 8 & 10.6 & -2.6 & 2.1 \\
\hline Castile and Leon & 69 & 5.2 & 4.6 & 0.6 & 2.9 \\
\hline Castilla-La Mancha & 68 & 5.1 & 4.3 & 0.8 & 3.4 \\
\hline Galicia & 61 & 4.6 & 5.8 & -1.2 & 2.3 \\
\hline Basque Country & 45 & 3.4 & 5.2 & -1.8 & 2.0 \\
\hline Canary Islands & 45 & 3.4 & 4.6 & -1.2 & 2.1 \\
\hline Aragon & 41 & 3.1 & 2.8 & 0.3 & 3.1 \\
\hline Extremadura & 34 & 2.6 & 2.3 & 0.3 & 3.2 \\
\hline Region of Murcia & 32 & 2.4 & 3.2 & -0.8 & 2.2 \\
\hline Balearic Islands & 26 & 2 & 2.4 & -0.4 & 2.3 \\
\hline Chartered Community of Navarre & 25 & 1.9 & 1.4 & 0.5 & 3.9 \\
\hline Principality of Asturias & 25 & 1.9 & 2.2 & -0.3 & 2.4 \\
\hline Cantabria & 21 & 1.6 & 1.2 & 0.4 & 3.6 \\
\hline La Rioja & 10 & 0.8 & 0.7 & 0.1 & 3.2 \\
\hline Ceuta & 4 & 0.3 & 0.2 & 0.1 & 4.7 \\
\hline
\end{tabular}

Notes: No active digital-native news media were found in the Autonomous City of Melilla (population: 86,384). It was not possible to identify the location of 58 digital-native media for this census. Source for website data: Authors' own database. Source for population data: INE (2016).

these represented $97 \%$ of all active digital-native news media, whereas just around $1.5 \%$ of them (21) were owned by public institutions directly, and ownership could not be determined for another $1.5 \%$ (20). The weighting was similar among inactive digital-native news media, with 229 private sites and 7 public ones, but ownership could not be determined for more than one in three of these sites which were no longer in operation. 


\subsection{Advertisements Dominate Revenue Sources}

Among all the ways to fund online news operations, $89.2 \%(1,233)$ of all active digital-native sites carried advertising; $14.8 \%$ (204) received funding in the form of sponsorship from public institutions, a category comprising governmental programs that support media in minority languages, or cultural or regional development; $6.4 \%$ (89) included branded or sponsored content; $5.2 \%(72)$ had some kind of private sponsorship; $4.9 \%$ (68) accepted donations, and 4\% (55) sold subscriptions. Other sources of revenue included online shops, selling either editorial products or any other kinds of merchandise (in more than 20 instances); digital communications services; and management or consultancy offered by the publishing company to other businesses and organizations. In addition, there were a few voluntary membership schemes designed for committed users to support the news outlet, which cannot be considered as standard subscriptions.

\section{Conclusion}

The present quantitative study of digital-native news media has enabled us to present an updated and representative profile of such media in the context of online news media in Spain. The paradox of the surge in digitalnative media we describe is that it occurred during a series of economic, political, and media industry crises of historic proportions. Not only was the media industry in crisis during the past decade, drained of advertising revenue by search and social platforms, but the economy of Spain and Western Europe was suffering from a Great Recession. One would expect that people would be less likely to support media with their own financial resources.

However, the surge in new media follows the pattern of creative destruction described by economic theorists from Marx to Schumpeter (Elliott, 1980): The failure of old methods and models stimulates innovation and opens the way for entrepreneurs willing to experiment with developing new revenue sources, narrative formats, distribution channels, production methods, and differentiated content.

Responding to RQ1, in 2019, there were 1,382 active digital-native media in Spain and they represented $46.4 \%$ of all active digital publications in the country. In addition to that, 8 of the 25 most-read online media brands were digital-native, with three of them in the top 10 (see Table 3). These sites have been growing and invigorating the media industry with their innovations. For this reason, journalism across the industry has become much more entrepreneurial, and we can affirm with Bradshaw (2018, p. 1): "This is a period of enormous creativity and change, a time when young journalists (and many older ones) have a unique opportunity to try new things, learn and grow quickly and innovate in a completely new form of storytelling."
As mentioned earlier, it seems paradoxical that the creation of digital-native media in Spain would peak at the height of the media crisis, which saw the closing of hundreds of media outlets and the layoff of at least 12,000 journalists. However, many of these displaced journalists tried to fill some of the gaps left by failed media and they kept working as journalists. They took advantage of their severance pay, which is relatively generous for long-term, well-paid employees under Spanish law, to support themselves while launching digital publications. They built their websites using free or low-cost publishing technology tools that were becoming available. But while the founders of these startups may have understood journalism, many didn't know much about business: one-fifth of new media founded by journalists in this context (121) had closed or were inactive by 2015 (APM, 2015, p. 82).

The biggest problem for these media was that their founders did not have a business plan or commercial focus, the APM (2015, p. 87) report concluded. A third of their publications had revenues of less than 25,000 euros a year; almost $60 \%$ were generating $25,000-50,000$ euros, scarcely enough to keep one or two people gainfully employed. Almost two-thirds of them were counting on advertising or sponsorship to generate revenue at a time when advertisers were fleeing to the more targeted, more efficient search and social platforms.

In relation to $R Q 2$, along with the very widespread reliance on advertising as the default source of revenue, we can describe a landscape of almost exclusively privately-owned digital-native sites, located disproportionately more in the Madrid metropolitan region, and with more of the general-interest than of the specialist kind. Among the latter, the dominant topics fit into the broad categories of Sport and Culture, as each of them makes around $20 \%$ of specialist sites, whereas hard news themes such as Business and Finance, and Politics, just fall short of $7 \%$ and $5 \%$ respectively.

At the end of the 2010s, the decade that was stirred by the Great Recession, reader-funded digital-native initiatives are a small minority, not reaching one in ten cases in total, either by compulsory subscription or with voluntary donations or a membership program. Even when they exist, they usually come in combination with the support of advertisers or institutions. Only a few digital natives attempted to add value to their editorial and commercial proposition through expansion into a multiplatform media presence in the form of mobile applications, or with weekly, monthly, or fortnightly print products, or digital radio or television spin-offs.

The potential sustainability of these digital natives can be seen more clearly through the lens of Picard (2010). He viewed the heavy dependence of news organizations on advertising as a formula for long-term loss of readers, revenue, and influence. He argued that publishers' relentless quest for bigger audiences to satisfy advertisers creates little value for users. If all media are covering the same breaking news events, natural disas- 
ters, and celebrity scandals, the result is "excessive sameness," he said, in reference to Hotelling's law for market economics (Picard, 2010, p. 18). Picard (2010) went on to explain that readers do not value this information enough to pay for it, especially when many outlets offer such content free on their websites to attract clicks. The organizations that survive will have to be differentiated and innovative.

A problem with Spain's digital-native news organizations is that they have been slow to develop new business models. Newman (2019) surveyed 200 digital news leaders at major publications from 29 countriesincluding 40 editors-in-chief, 30 CEOs or managing directors, and 30 heads of digital-on their plans and projections for the future of their organizations. Among the trends they emphasized were the importance of "labelling and prioritising" trusted content to build credibility with the public. Related to that was "a shift toward user payment as a core business model" (Newman, 2019, p. 44). Even publishers that rely on advertising "are refocusing on loyalty and building relationships over time" (Newman, 2019, p. 44). The emphasis is on news as a public service. The data in our research suggests that Spain's media have not yet pivoted sufficiently in that direction.

Picard (2010) contended that the future of news organizations as sustainable enterprises requires focusing more on users than on advertisers. It lies in creating specialized content sufficiently differentiated that people perceive value in it for themselves, enough that they will pay for it: "Only by being distinct can one achieve higher value and profit" (Picard, 2010, p. 111). A news publisher's survival, as he saw it, depends on creating a greater quantity of original content that is relevant to users: "How well products and services solve consumers' problems, ease the tasks and challenges of life, and satisfy other needs are an important part in the perception of their value" (Picard, 2010, p. 51).

In that context, two of the most successful digital natives in Spain bolster his arguments: El Confidencial and Eldiario.es. In describing themselves and their value propositions, both accentuate that they serve the interests of the public first and that they are independent of commercial and political interests that could influence their coverage. They emphasize the importance of financial independence in maintaining editorial independence.

El Confidencial was founded before the crisis, in 2002, and it focuses on business, the economy, and politics. It has a stated mission of "contributing to a freer and better-informed society" (El Confidencial, 2019). It has a business model based on advertising, but a significant percentage of that is native advertising, also called sponsored content, which aims to align itself with the values and the mission of the publication. It reported $2018 \mathrm{rev}$ enues of a record 18.2 million euros, up $17 \%$ from the previous year, and after-tax earnings of 3.3 million. Its newsroom has grown to 95 journalists, with 155 employ- ees overall. Its events business grew $30 \%$ over the previous year (El Confidencial, 2019). In September 2019, it began offering a premium subscription product aimed at business users.

Eldiario.es, founded well into the crisis, in 2012, has attracted attention with a revenue model supported by 35,000 members, who pay a minimum of 60 euros a year, not for access to content but to support independent investigative journalism for all. The site generated an estimated 5.7 million euros in annual revenues in 2018, up $19 \%$, with close to 2 million euros coming from the members (Escolar, 2018). The company has grown its profit every year and it has reinvested it in the product: It grew its staff from 72 to 83 in 2018. The site has free access, but the members receive some extra benefits: They can hide the advertisements, they can access some content a few hours ahead of the non-paying users, they get a quarterly print publication, and they receive some discounts and passes to events. Its mission is "to hold the powerful accountable, to protect freedom, and promote a sustainable society. We defend human rights, equality, and a better democracy" (eldiario.es, n.d.).

These two examples are among the few that are thriving while producing news in the public interest, with a reputation for editorial independence and fair working and pay conditions. However, the latest annual APM report to date described the work environment for journalists in Spain as "hostile" (APM, 2019, p. 6). According to the professional survey in this report, $44 \%$ of freelance journalists worked for a digital daily outlet, as opposed to $26 \%$ of staff journalists, and $30 \%$ of freelancers worked for digital magazines, which only employed $5 \%$ of all news media staffers (APM, 2019, p. 9).

At the same time, the overall failure rate of digital natives should not be a cause for pessimism or alarm. The vast majority of startups in all industries fail within a few years. The good news is that so many have survived and that some have actually prospered. As successful digital launches become established incumbents that make up a considerable share of the market, according to Schumpeter's (1942) theory they need not only to adapt to changes but also to continue to disrupt what making news media means in the online world, as new products and services compete for users' time and money. The context can be uncertain - not only for legacy media but also for digital-native ones-but "survival is a precondition for success" (Bruno \& Nielsen, 2012, p. 100). As part of the process of creative destruction, failed media enterprises become learning experiences for some who will try again.

\section{Acknowledgments}

This study received funding from the research project DIGINATIVEMEDIA, funded by the Spanish Ministry of Science, Innovation and Universities (No. RTI2018093346-B-C31). 


\section{Conflict of Interests}

The authors declare no conflict of interests.

\section{References}

Almiron, N., \& Segovia, A. I. (2012). Financialization, economic crisis, and corporate strategies in top media companies: The case of Grupo Prisa. International Journal of Communication, 6, 2894-2917. Retrieved from https://ijoc.org/index.php/ijoc/article/ view/1793

Arrese, Á., \& Vara-Miguel, A. (2016). A comparative study of metaphors in press reporting of the Euro crisis. Discourse \& Society, 27(2), 133-155. https://doi.org/ $10.1177 / 0957926515611552$

Asociación de la Prensa de Madrid. (2015). Informe anual de la profesión periodística 2015 [Annual report of the journalistic profession 2015]. Madrid: Asociación de la Prensa de Madrid. Retrieved from https:// www.apmadrid.es/wp-content/uploads/2016/11/ INFORME-PROFESION-APM-2015_baja_7M.pdf

Asociación de la Prensa de Madrid. (2019). Informe anual de la profesión periodística 2019 [Annual report of the journalistic profession 2019]. Madrid: Asociación de la Prensa de Madrid.

Asociación de Medios de la Información de España. (2019). Informe i2p inversión publicitaria [i2p report on advertising investment]. Madrid: Asociación de Medios de la Información de España. Retrieved from https://www.ami.info/wp-content/uploads/2019/ 10/i2p_primer_semestre_2019.pdf

Asociación para la Investigación de Medios de Comunicación. (2019). Marco general de los medios en España 2019 [General media framework in Spain 2019]. Madrid: Asociación para la Investigación de Medios de Comunicación. Retrieved from https://www.aimc. es/a1mc-c0nt3nt/uploads/2019/01/marco19.pdf

Boomgaarden, H., van Spanje, J., Vliegenthart, R., \& de Vreese, C. (2011). Covering the crisis: Media coverage of the economic crisis and citizens' economic expectations. Acta Polita, 46, 353-379. https://doi.org/ 10.1057/ap.2011.18

Boyles, J. L. (2016). The isolation of innovation: Restructuring the digital newsroom through intrapreneurship. Digital Journalism, 4(2), 229-246. https://doi. org/10.1080/21670811.2015.1022193

Bradshaw, P. (2018). The online journalism handbook. Oxford and New York, NY: Routledge.

Bruno, N., \& Nielsen, R. K. (2012). Survival is success: Journalistic online start-ups in Western Europe. Oxford: Reuters Institute for the Study of Journalism. Retrieved from https://reutersinstitute.politics.ox. ac.uk/sites/default/files/2017-12/Survival\%20is\%20 Success\%20Journalistic\%20Online\%20Start-Ups\%20 in\%20Western\%20Europe.pdf

de Toro, J. M., Soldado, P., San Pedro, M., Breiner, J., Arrese, Á., Vara-Miguel, A., . . Bel, I. (2017). La prensa digital en España 2016 [Digital media in Spain 2016]. Madrid: Institute for Media \& Entertainment and School of Communication, Universidad de Navarra.

Doyle, G. (2013). Re-invention and survival: Newspapers in the era of digital multiplatform delivery. Journal of Media Business Studies, 10(4), 1-20. https://doi.org/ 10.1080/16522354.2013.11073569

El Confidencial. (2019). El Confidencial cumple 18 años líder en audiencia y beneficios [El Confidencial completes its 18th year as a leader in audience and profits]. El Confidencial. Retrieved from https://blogs. elconfidencial.com/comunicacion/en-contacto/ 2019-06-20/elconfidencial-18aniversario-lideraudiencia-beneficios_2079513

Eldiario.es. (n.d.). ¿Por qué eldiario.es necesita socios y socias y otros medios no? [Why does eldiario.es need members and other news organizations don't?]. Eldiario.es. Retrieved from https://l.eldiario.es/porque-necesitamos-socios

Elliott, J. E. (1980). Marx and Schumpeter on capitalism's creative destruction: A comparative restatement. The Quarterly Journal of Economics, 95(1), 45-68. https://doi.org/10.2307/1885348

Escolar, I. (2018). Las cuentas de eldiario.es en su sexto aniversario [The financial results of eldiario.es on its sixth anniversary]. Eldiario.es. Retrieved from https://www.eldiario.es/escolar/cuentas-eldiarioessexto-aniversario_6_818628133.html

Foster, R., \& Kaplan, S. (2011). Creative destruction: Why companies that are built to last underperform the market-And how to successfully transform them. New York, NY: Currency.

García-Avilés, J. A., \& González-Esteban, J. L. (2012). Cibermedios nativos españoles: Explorando modelos de rentabilidad [Digital-native media in Spain: Exploring profitable models]. Trípodos, 30, 153-167.

Gershon, R. A. (2013). Innovation failure: A case study analysis of Eastman Kodak and Blockbuster Inc. In G. Albarran (Ed.), Media management and economics research in a transmedia environment (pp. 62-84). London: Routledge.

González-Esteban, J. L. (2014). La transformación del ecosistema mediático español: El caso de eldiario.es [The transformation of the Spanish media ecosystem: The case of eldiario.es]. Revista Mediterránea de Comunicación, 5(2), 159-173. https://doi.org/ 10.14198/MEDCOM2014.5.2.10

Grusky, D. B., Western, B., \& Wimer, C. (Eds.). (2011). The great recession. New York, NY: Russell Sage Foundation.

Hass, B. H. (2011). Intrapreneurship and corporate venturing in the media business: A theoretical framework and examples from the German publishing industry. Journal of Media Business Studies, 8(1), 47-68. https://doi.org/10.1080/16522354. 2011.11073518

Instituto Nacional de Estadística. (2016). Cifras de Población a 1 de enero de 2016 [Population fig- 
ures on January 1, 2016]. Madrid: Instituto Nacional de Estadística. Retrieved from https://www.ine.es/ prensa/np980.pdf

Instituto Nacional de Estadística. (2019a). Encuesta de población activa. Parados. Total nacional. Ambos sexos. Información y comunicaciones. Personas [Economically active population survey. Unemployed persons. National total. Both sexes. Information and communication. Persons]. Instituto Nacional de Estadistica. Retrieved from https://www.ine.es/ consul/serie.do?d=true \&s=EPA66453\&nult=0

Instituto Nacional de Estadística. (2019b). Gross domestic product (Statistical review 2019). Instituto $\mathrm{Na}$ cional de Estadística. Retrieved from https://www. ine.es/en/prensa/pib_tabla_cne_en.htm

$\mathrm{Ku}$, R. S. R. (2002). The creative destruction of copyright: Napster and the new economics of digital technology. The University of Chicago Law Review, 69(1), 263-324. Retrieved from https://www.jstor. org/stable/1600355

Kurtz, H. (2002, September 30). Robotic journalism: Google introduces human-less news. The Washington Post. Retrieved from https://andrewcoile. com/CSUMB/2002/fall/CST373/scrapbook/ robotjournalism.pdf

Nee, R. C. (2013). Creative destruction: An exploratory study of how digitally native news nonprofits are innovating online journalism practices. International Journal on Media Management, 15(1), 3-22. https:// doi.org/10.1080/14241277.2012.732153

Newman, N. (2019). Journalism, media, and technology trends and predictions. Oxford: Reuters Institute for the Study of Journalism. Retrieved from https:// reutersinstitute.politics.ox.ac.uk/our-research/ journalism-media-and-technology-trends-andpredictions-2019

Pérez-Latre, F. J. (2014). Legacy media: A case for creative destruction? Palabra Clave, 17(4), 1097-1113. http://dx.doi.org/10.5294/pacla.2014.17.4.5

Picard, R. G. (2010). Value creation and the future of news organizations: Why and how journalism must change to remain relevant in the twenty-first century. Lisbon: MediaXXI.

Picard, R. G. (2014). Twilight or new dawn of journalism? Digital Journalism, 2(3), 273-283. https://doi.org/ 10.1080/21670811.2014.895531

Salaverría, R. (2008). Ciberperiodismo: Diez años de prensa digital en España [Cyberjournalism: Ten years of digital media in Spain]. In J. J. Fernández Sanz (Ed.), Prensa especializada: Doce calas [Specialized media: Twelve insights] (pp. 355-383). Madrid: McGraw-Hill.

Salaverría, R. (2015). Los labs como fórmula de innovación en los medios [Labs as a formula for media innovation]. El Profesional de la Información, 24(4), 397-404. https://doi.org/10.3145/epi.2015.jul.06

Salaverría, R. (2019). Digital journalism: 25 years of research. Review article. El Profesional de la Información, 28(1), 1-26. https://doi.org/10.3145/epi.2019. ene.01

Salaverría, R., \& Gómez-Baceiredo, B. (2017). Spain. Media Landscapes. Retrieved from https://media landscapes.org/country/spain

Salaverría, R., Martínez-Costa, M. P., \& Breiner, J. (2018). Mapa de los cibermedios de España en 2018: Análisis cuantitativo [Map of digital news media in Spain in 2018: Quantitative analysis]. Revista Latina de Comunicación Social, 73, 1034-1053. http://dx.doi.org/ 10.4185/RLCS-2018-1295

Salles, C. (2019). Disrupting journalism from scratch: Outlining the figure of the entrepreneur-journalist in four French pure players. Nordic Journal of Media Studies, 1(1), 29-46. https://doi.org/10.2478/njms2019-0003

Schlesinger, P., \& Doyle, G. (2015). From organizational crisis to multi-platform salvation? Creative destruction and the recomposition of news media. Journalism, 16(3), 305-323. https://doi.org/ $10.1177 / 1464884914530223$

Schumpeter, J. A. (1942). Socialism, capitalism and democracy. New York, NY: Harper and Bros.

Vara-Miguel, A., Negredo, S., Amoedo, A., \& Moreno, E. (2019). Digital news report.es 2019. Más y mejor periodismo: Un remedio contra la desinformación [Digital news report (Spain) 2019. More and better journalism: A remedy for disinformation]. Digital news report.es 2019. Retrieved from https://www. digitalnewsreport.es/category/2019

Vliegenthart, R., \& Mena Montes, N. (2014). How political and media system characteristics moderate interactions between newspapers and parliaments: Economic crisis attention in Spain and the Netherlands. The International Journal of Press/Politics, 19(3), 318-339. https://doi.org/10.1177/1940161 214531335

\section{About the Authors}

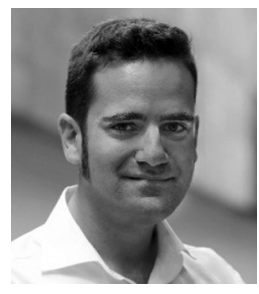

Samuel Negredo (PhD) is Associate Professor at the School of Communication of the University of Navarra, where he is Deputy Director of International Relations. He teaches digital media editing and design. His research encompasses online news video, interactive documentaries, user participation in broadcast and online journalism, media convergence, and online news audiences. Since 2014, he is a national contributor to the Reuters Institute Digital News Report and a Coauthor of the Digital News Report Spain briefing. 


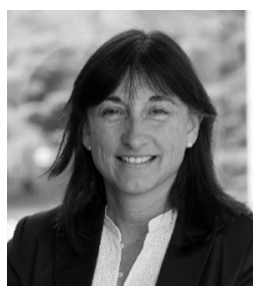

María-Pilar Martínez-Costa (PhD) is Associate Professor of Journalism at the School of Communication of the University of Navarra. Since 2014, she is Director of the Journalism Projects Department. She investigates the processes of innovation, production, distribution, and marketing of radio broadcasting and media in the digital environment within the University of Navarra research line "Communication and New Technologies." On this topic, she has published more than 80 articles and book chapters in national and international indexed publications, and she has participated in research projects, presenting papers and communications in several national and international conferences.

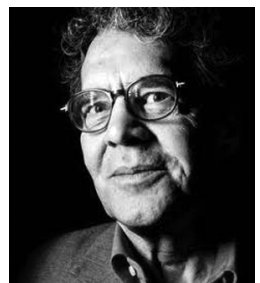

James Breiner (MA) is a Bilingual Consultant (English-Spanish) on digital journalism and newsroom leadership with three decades of experience on the editorial and business sides of newspapers Currently, he is Assistant Professor in the School of Communication, Department of Marketing and Media Businesses, at the University of Navarra in Pamplona, Spain. His specialty is entrepreneurial journalism, or new financial models for digital media. His blogs about entrepreneurial journalism are in English and Spanish at www.jamesbreiner.com. He has an MA in English Literature from the University of Connecticut, USA.

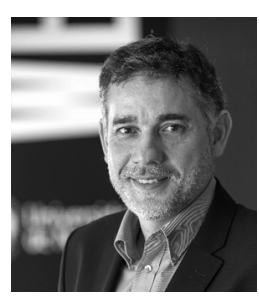

Ramón Salaverría (PhD) is Associate Professor of Journalism at the University of Navarra, where he serves as Associate Dean of Research at the School of Communication. Counting over 200 scholar publications, his research focuses on digital journalism, mostly on digital news media production. He was Chair of the Journalism Studies Section of ECREA in the term 2010-2012. 